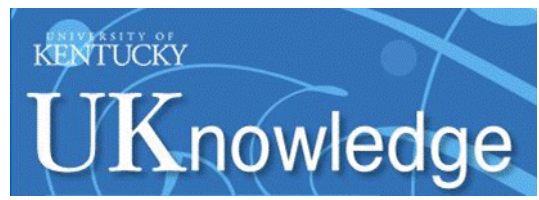

University of Kentucky

UKnowledge

Biosystems and Agricultural Engineering Faculty Publications

\title{
Evaluation of Flocculation, Sedimentation, and Filtration for Dewatering of Scenedesmus Algae
}

\author{
Nicholas A. Rhea \\ University of Kentucky, nrhea@charah.com \\ Jack Groppo \\ University of Kentucky, john.groppo@uky.edu \\ Czarena Crofcheck \\ University of Kentucky, crofcheck@uky.edu
}

Follow this and additional works at: https://uknowledge.uky.edu/bae_facpub

Part of the Algae Commons, Bioresource and Agricultural Engineering Commons, and the Oil, Gas, and Energy Commons

Right click to open a feedback form in a new tab to let us know how this document benefits you.

\section{Repository Citation}

Rhea, Nicholas A.; Groppo, Jack; and Crofcheck, Czarena, "Evaluation of Flocculation, Sedimentation, and Filtration for Dewatering of Scenedesmus Algae" (2017). Biosystems and Agricultural Engineering Faculty Publications. 27.

https://uknowledge.uky.edu/bae_facpub/27

This Article is brought to you for free and open access by the Biosystems and Agricultural Engineering at UKnowledge. It has been accepted for inclusion in Biosystems and Agricultural Engineering Faculty Publications by an authorized administrator of UKnowledge. For more information, please contact UKnowledge@lsv.uky.edu. 
Evaluation of Flocculation, Sedimentation, and Filtration for Dewatering of Scenedesmus Algae

Digital Object Identifier (DOI)

https://doi.org/10.13031/trans.12116

Notes/Citation Information

Published in Transactions of the ASABE, v. 60, issue 4, p. 1359-1367.

(C) 2017 American Society of Agricultural and Biological Engineers

The copyright holder has granted the permission for posting the article here.

This article is available at UKnowledge: https://uknowledge.uky.edu/bae_facpub/27 


\title{
EVALUATION OF Flocculation, SEDIMENTATION, AND FILTRATION FOR DEWATERING OF SCENEDESMUS ALGAE
}

\author{
N. Rhea, J. Groppo, C. Crofcheck
}

\begin{abstract}
Algae can be used as a feedstock for agricultural fertilizers, livestock and poultry feeds, anaerobic digestion, and biofuel production. For each end product, the requirements for moisture content (or solids content) vary, such that a desirable water removal strategy needs to be adaptable to varying levels of water removal. Flocculation, sedimentation, and filtration were evaluated as possible strategies for thickening and dewatering of algae. The goal of this study was to validate that algae cells treated by such means could be processed by vacuum belt filters and to determine the conditions under which the solids content could be increased to 5 to $25 \mathrm{wt} \%$. The flocculation and sedimentation studies focused on conditions needed to thicken algae from a culture concentration range of 0.4 to $1 \mathrm{~g} \mathrm{~L}^{-1}$ to an end-product concentration range of 15 to $50 \mathrm{~g} \mathrm{~L}^{-1}$. Sedimentation rates of Scenedesmus actus were measured with varying flocculant dosages (0 to $25 \mathrm{ppm}$ ) for various flocculants. The highest level of compaction was achieved with a synthetic cationic polymeric flocculant with higher molecular weight at a dosage of $15 \mathrm{ppm}$, which provided $16.3 \mathrm{~mL}$ of compacted solids (3.3 wt\% solids). Subsequently, solids were successfully separated as a cake via gravity and vacuum filtration. The filtration studies focused on the conditions needed to filter flocculated algae slurry from a concentration range of 15 to $50 \mathrm{~g} \mathrm{~L}^{-1}$ to a product at a concentration range of 50 to $250 \mathrm{~g} \mathrm{~L}^{-1}$. Filtration rates of Scenedesmus actus were measured on algae slurry treated with 10 to 15 ppm of a synthetic cationic polymeric flocculant. Processing parameters such as cake formation time, filtration rate, and mass throughput were evaluated against variables such as cake thickness, feed concentration, and processing time.
\end{abstract}

Keywords. Algae, Dewatering, Filtration, Flocculation, Scenedesmus sp., Sedimentation, Thickening.

$\mathrm{T}$ he utilization of algae for alternative fuels and mitigation of $\mathrm{CO}_{2}$ emissions has the potential to address many energy and environmental challenges (Zhuo et al., 2015). For both applications, success will depend on growing large amounts of algae, harvested continuously to maintain a stable algae culture. Algae are typically harvested at a dilute concentration of $0.02 \%$ to $0.06 \%$ TSS (total suspended solids), but recovered algae need to be closer to $5 \%$ to $25 \%$ TSS or higher for further processing (Shelef et al., 1984). Recovery of a large volume of water from the algae harvest $\left(0.4\right.$ to $\left.1 \mathrm{~g} \mathrm{~L}^{-1}\right)$ allows the water to be sterilized and returned to the algae culture vessels, reducing water requirements and contamination. Individual algae cells of interest are approximately $5 \mu \mathrm{m}$ in size, contain $80 \%$ intercellular water, and have a density of $\sim 1.0 \mathrm{~g}$ $\mathrm{cm}^{-3}$. Given the small size and nearly neutral density of algae cells, natural sedimentation is a very slow process; thus, increasing the sedimentation rate with the addition of flocculants is desirable.

Submitted for review in September 2016 as manuscript number PRS 12116; approved for publication by the Processing Systems Community of ASABE in March 2017.

The authors are Nicholas Rhea, Graduate Student, Department of Biosystems and Agricultural Engineering, Jack Groppo, Professor, Department of Mining Engineering and Center for Applied Energy Research, and Czarena Crofcheck, ASABE Member, Professor, Department of Biosystems and Agricultural Engineering, University of Kentucky, Lexington, Kentucky. Corresponding author: Czarena Crofcheck, 128 C.E. Barnhart Building, University of Kentucky, Lexington, KY 40546; phone: 859-218-4349; e-mail: crofcheck@uky.edu.
It is well recognized that an effective harvesting strategy is a critical component of any large-scale algae utilization process. A desirable strategy would be to recover biomass in a thickened state for subsequent utilization, while simultaneously producing clarified growth medium that can be recycled back into the growth system. Most commercial harvesting efforts to date have focused on centrifugation and dissolved air flotation (DAF). While technically feasible, these options can be expensive due to the significant capital and operating costs. One option to reduce these costs is to adopt an effective thickening strategy prior to centrifugation, which would significantly reduce the volume of solids to be treated. This study focused on using polymeric flocculants to enhance initial solid/liquid separation for this purpose. Once thickened, algal biomass would be amenable to further dewatering by centrifugation or by other means, such as filtration.

The harvesting system evaluated in this work included flocculation with sedimentation followed by filtration (fig. 1). These unit operations were selected because they are standard thickening processes used in commercial applications, such as wastewater treatment and mineral processing (EPA, 1987). The resulting thickened slurry (20 to $50 \mathrm{~g} \mathrm{~L}^{-1}$ ) after flocculation with sedimentation enables direct utilization of algae for methane production via anaerobic digestion. Further dewatering by filtration produces an algae paste ( 80 to $120 \mathrm{~g} \mathrm{~L}^{-1}$ ) amenable to wet lipid extraction for biodiesel production, hydrothermal liquefaction to hydrocarbons, or anaerobic digestion for the production of methane. Other potential uses, such as biodiesel production via dry lipid extrac- 


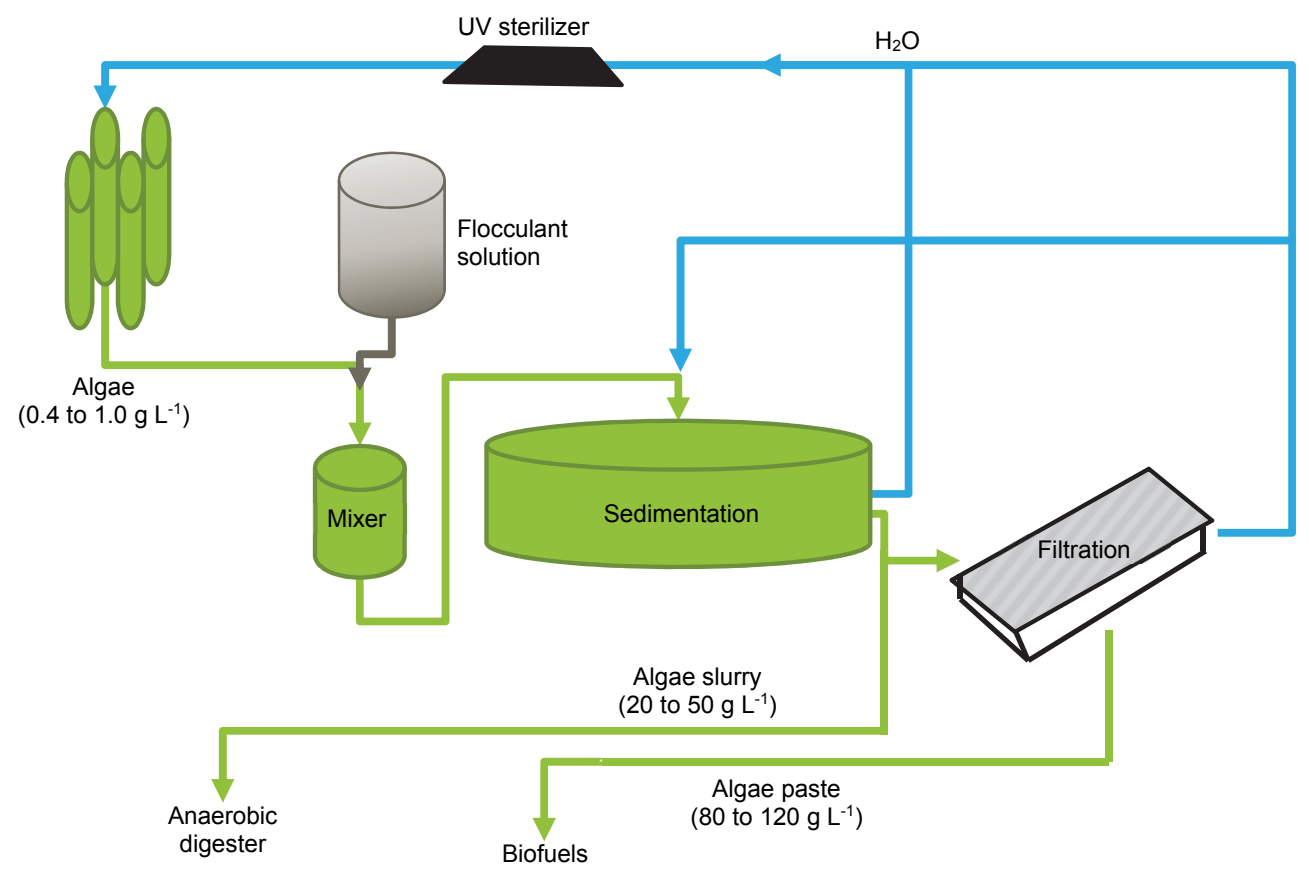

Figure 1. Algae harvest process diagram showing flocculation, sedimentation, and filtration.

tion or bioplastic production, require moisture reduction to levels that can only be achieved by thermal drying (i.e., $<10 \%$ moisture). While thickening and filtration cannot achieve these moisture levels alone, they are essential steps for removing substantial water prior to thermal drying processes that require significant energy inputs.

Algal biomass is very difficult to dewater with standard separation technology and equipment because its density is so close to that of the water in which it is suspended. The cells have little to no structural rigidity, which limits the force that can be applied before deformation or shear overwhelms the cells. These problems have been noted in previous work with centrifugation (Divakaran et al., 2002) and pressurized filtration (Sim et al., 1988) of algae. Further, operational costs are high for centrifugation, and physical constraints make pressure-driven filtration impractical. Efficiency could potentially be improved through utilization of cationic polymeric flocculants, as proposed in previous research; however, floc structure integrity in high velocity/shear environments is unknown.

Various chemical flocculants have been evaluated to increase the sedimentation of algae, including alum (Golueke and Oswald 1965; McGarry 1970; Moraine et al. 1980), ferric sulfate (Bare et al., 1975; Moraine et al., 1980), lime, and magnesium hydroxide (Folkman and Wachs, 1973; Friedman et al., 1977), as well as chitosan (Nigam et al., 1980). While these materials can induce flocculation, the large dosages required, the need for $\mathrm{pH}$ control, and the introduction of soluble ions into the recycled water preclude this approach for continuous large-scale applications. Because of these limitations, polymeric flocculants were selected for evaluation as sedimentation aids. Polymeric flocculants are widely used in a number of industrial water treating applications, such as municipal waste and mineral processing water treatment (Shelef et al., 1984). In addition to wide availability, other significant advantages of using polymeric floccu- lants compared to inorganic additives are the significantly lower dosage (5 to $10 \mathrm{ppm}$ versus 100 to $750 \mathrm{ppm}$ ), elimination of the need for $\mathrm{pH}$ manipulation, and avoidance of introducing excessive inorganic species into the recycled water that can inhibit algae growth.

For successful flocculation, the charge, charge density, and molecular weight of the polymeric flocculant are important considerations for selecting the appropriate flocculant. Stable particulate suspensions are characterized by a high zeta potential, indicating that electrostatic repulsive forces within the electrical double layer surrounding each particle limit particle migration within a distance close enough for shorter-range attractive forces to operate; thus, the highly charged particles remain in suspension. The addition of large polymeric flocculant molecules of opposite charge provides charged active sites for oppositely charged particles to adsorb. If the flocculant molecules are sufficiently large to provide numerous adsorption sites, then floc formation occurs. The electrostatic attractive forces of oppositely charged particulates and flocculant molecules in this type of system are considered the primary mechanism for adsorption. Active sites on long-chain polymers can induce further aggregation of flocs by attachment via bridging mechanics (Somasundaran, 1980). With selection of the appropriate polymeric flocculant, a dilute suspension of algae cells can be induced to form flocs of sufficient size to promote effective settling despite the small size and neutral density of algae cells.

To produce dry biomass, spray dryers have been suggested to efficiently remove all moisture (Shelef et al., 1984). Other options, such as electro-coagulation (Vandame et al., 2011) and froth flotation (Chen et al., 1998), have also been proposed but are unproven in large-scale applications. Regardless of the drying option applied, mechanically removing free water prior to drying would substantially reduce the emissions and cost associated with the high energy de- 
mands of drying, making processing methods such as cake filtration appealing.

In order to effectively extract additional free water with cake filtration, appropriate filter media must be selected to support cake establishment and withstand any elevated pressure gradient applied in order to increase filtrate throughput. Processing parameters such as cake thickness, feed concentration, air velocity (controlled by pressure), and rate of filtration $\left(\mathrm{L} \mathrm{m}^{-2} \mathrm{~min}^{-1}\right)$ are important considerations for filtering algae on a large scale.

The specific objectives of this study include (1) selection of appropriate flocculants, (2) evaluation of flocculant effect on sedimentation, and (3) evaluation of filtration performance using gravity and vacuum filtration.

\section{MATERIALS AND METHODS}

\section{Algae Cultivation}

Scenedesmus actus microalgae (UTEX B72) was cultivated in $8 \mathrm{~L}$ ( $4 \mathrm{ft}$ tall $\times 5$ in. diameter) airlift reactors using tap water sterilized with a UV filter and urea media (Crofcheck et al., 2012). The urea media included $0.138 \mathrm{~g} \mathrm{~L}^{-1}$ of urea, $0.14 \mathrm{~g}$ $\mathrm{L}^{-1}$ of TS phosphate, $0.068 \mathrm{~g} \mathrm{~L}^{-1}$ potash, and $0.026 \mathrm{~g} \mathrm{~L}^{-1}$ Sprint 330 EDTA. The culture was grown outdoors under natural light and continually sparged with a mixture of compressed $\mathrm{CO}_{2}(12 \% \mathrm{v} / \mathrm{v})$ and air to simulate coal combustion flue gas. The algae culture was periodically harvested when the culture density was $>0.4 \mathrm{~g} \mathrm{~L}^{-1}$ on a dry mass basis. Scenedesmus sp. biomass samples in suspension were filtered using Whatman binder-free glass microfiber filters (type 934-AH, $1.5 \mu \mathrm{m}$ pore size). The dry weights of samples were measured after drying at $105^{\circ} \mathrm{C}$ for $24 \mathrm{~h}$. Biomass content was calculated as the microalgae dry weight produced per liter $\left(\mathrm{g} \mathrm{L}^{-1}\right)$. The remaining culture make-up water was diluted with water containing additional nutrients at the appropriate levels to return the culture to full strength to avoid nutrient depletion.

\section{Zeta Potential}

The electrokinetic properties of algae cells were characterized by determination of the zeta potential using a ZetaMeter GT-2 electrophoresis cell. A $1 \mathrm{~mL}$ sample of algae suspension was collected from the $8 \mathrm{~L}$ airlift reactors and diluted with $50 \mathrm{~mL}$ of a $10^{-4}$ molar solution of $\mathrm{NaCl}$ prepared with distilled deionized water to maintain constant ionic strength. The sample was mixed using a magnetic stirrer, and $\mathrm{pH}$ adjustments were made using $\mathrm{HCL}$ or $\mathrm{NaOH}$. Once the pH stabilized, the sample was transferred into the electrophoresis cell. DC voltage was applied to electrodes at opposite ends of the cell. As algae cells migrated to electrodes of opposite charge, the time required to move between fixed distances on a calibrated scale was recorded. Measurements were taken for a minimum of ten particles at each $\mathrm{pH}$ value; the average and standard deviation of zeta potential for each $\mathrm{pH}$ measurement were recorded. After measurement, the electrophoresis cell was thoroughly cleaned and rinsed prior to the next measurement.

\section{FlocCUlant SELECTION}

In accordance with results from McGarry (1970), it was
Table 1. Cationic flocculants used for sedimentation experiments.

\begin{tabular}{cccc}
\hline Zinkan Product & Form & Charge & MW \\
\hline 6702 DADMAC & Dry powder & $100 \%$ & Medium \\
540 Polyacrylamide & Liquid solution & $50 \%$ & High \\
440 Polyacrylamide & Liquid solution & $40 \%$ & Low \\
\hline
\end{tabular}

determined that cationic flocculants were most appropriate for flocculating algae cells. A series of cationic polyacrylamide flocculants (table 1) was selected for further evaluation and provided by Zinkan, Inc. The 540 and 440 flocculants were selected to provide a molecular weight (MW) range with similar charge density. An additional product was included because of its very high charge density; Zinkan 6702 is a medium MW diallyl dimethyl ammonium chloride (DADMAC) flocculant. Alum was also tested at a higher dosage for comparison with previous literature (Udaman et al., 2010; Sukenik et al., 1988).

\section{Settling Tests}

Settling performance was evaluated using Imhoff settling cones (1.0 L tapered cones with graduations) to enable measurement of settled solids volume as a function of time. The settling test procedure consisted of combining a $1.0 \mathrm{~L}$ volume of algae suspension and an appropriate dosage of flocculant into a $1.0 \mathrm{~L}$ beaker and then stirring for $1 \mathrm{~min}$ on a Super-Nuova four-position magnetic stirrer at $600 \mathrm{rpm}$ to ensure consistent low-shear mixing conditions. The flocculated volumes were then immediately transferred to $1.0 \mathrm{~L}$ Imhoff settling cones. At appropriate time intervals, the volume of the compacted solids was recorded and converted to mass based on the algal dry mass density. Settling tests were completed in triplicate, with results reported as an average. The sedimentation experiments were conducted with varying flocculant dosages and algal culture densities. The flocculant dosages tested were $2.5,5,10,20$, and $30 \mathrm{ppm}$, while the culture densities were $0.25,0.5,0.75$, and $1.0 \mathrm{~g} \mathrm{~L}^{-1}$. Using a pairwise t-test with a 0.05 level of significance, means with no significant difference were identified.

The culture density range was selected based on the anticipated productivity that would be expected from a largescale algae cultivation system focused on $\mathrm{CO}_{2}$ mitigation. While higher productivity levels would be expected for commercial large-scale operations aimed at producing algae products, the development activities conducted by the University of Kentucky, which focus on utilization of $\mathrm{CO}_{2}$ from coal-fired power plant emissions with Scenedesmus sp., have found that culture densities up to only $1.0 \mathrm{~g} \mathrm{~L}^{-1}$ were sustainable in pilot-scale demonstration (Wilson et al., 2016). In systems such as this, directed at $\mathrm{CO}_{2}$ capture for large power stations, the overall continuous production of algal biomass, corresponding to $\mathrm{CO}_{2}$ fixation rate, will necessarily be the primary driver in system design, as opposed to culture density being the primary driver for fuel production.

To achieve the range of algal culture densities required for testing, airlift reactors were cultivated until a high desired culture density $\left(1.0 \mathrm{~g} \mathrm{~L}^{-1}\right)$ was achieved. A sufficient quantity of culture was collected to perform the testing, which was performed within $12 \mathrm{~h}$ of sample collection. To complete the experiment on algae samples produced under the same growing conditions, diluting the harvested samples 
was determined to be the most effective method for obtaining lower culture densities. Dry mass determinations were made using representative $25 \mathrm{~mL}$ samples of the initial algae culture. The culture sample was vacuum filtered using Whatman $(0.45 \mu \mathrm{m}$ pore size $)$ filter media and then dried at $100^{\circ} \mathrm{C}$ for $24 \mathrm{~h}$. The dried samples were then placed in a desiccator for $1 \mathrm{~h}$ before weighing.

To quantify the water clarity, a $30 \mathrm{~mL}$ sample of supernatant was collected for turbidity measurement at the end of the $30 \mathrm{~min}$ settling time. The turbidity sample was withdrawn by pipette from the center of the Imhoff settling cone at a depth of $16 \mathrm{~cm}$. Turbidity was measured with a LaMotte turbidimeter, and measurements were repeated five times. Between measurements, the sample vial was shaken to redistribute any settled solids. Turbidity measurements are reported as an average of the five measurements.

\section{Filter Medium Selection}

Focusing on solids retention and filtration rate, several differing filter media were screened for use in algae filtration. A commercial-grade multifilament fabric filter medium, 901F (provided by WesTech Engineering, South Salt Lake, Utah), was selected for use. The $901 \mathrm{~F}$ filter medium is manufactured with strands of polypropylene fiber multifilament bundles woven in a one-over-one pattern.

Filter efficacy was tested using $200 \mathrm{~mL}$ of a flocculated algae slurry at a concentration of $47 \mathrm{~g} \mathrm{~L}^{-1}$. Samples were allowed to drain by gravity for $5 \mathrm{~min}$ before applying vacuum (20 in. Hg) for $1 \mathrm{~min}$. The filtrate mass was recorded for each experiment and then filtered with Whatman No. 1 paper $\left(11 \mu \mathrm{m}\right.$ pore size) and dried at $100^{\circ} \mathrm{C}$ for $24 \mathrm{~h}$ to estimate the algae flocs $(\sim 50 \mu \mathrm{m}$ in diameter) passing through the filter, which represented the amount of algae lost in the experiment. The residue on the filter was dried at $100^{\circ} \mathrm{C}$ to calculate the $\mathrm{wt} \%$ of solids lost.

\section{Filtration Tests}

In order to prepare samples for the filtration experiments, algae seed cultures were transferred from the airlift reactors to a $\sim 4,000 \mathrm{~L}$ bioreactor. Whenever the culture density exceeded $0.4 \mathrm{~g} \mathrm{~L}^{-1}$ dry mass concentration, a harvest volume of $1,000 \mathrm{~L}$ was withdrawn from the reactor, treated with $10 \mathrm{ppm}$ of Zinkan 540 cationic polyacrylamide flocculant, and mixed. The additive was given $16 \mathrm{~h}$ to ensure that sedimentation was complete. Supernatant was then decanted from the tank, leaving $\sim 20 \mathrm{~L}$ of algae slurry at $\sim 50 \mathrm{~g} \mathrm{~L}^{-1}$ concentration for use in the filtration experiments.

In one set of experiments, the concentration of algae slurry was held constant at $28.3 \mathrm{~g} \mathrm{~L}^{-1}$ while varying the feed volume at $200,300,400$, and $500 \mathrm{~mL}$. In another set of experiments, the volume of feed slurry was held constant at $400 \mathrm{~mL}$ while varying the feed concentration. This was accomplished by diluting the total volume of sample after each trial to obtain 50, 40, and $30 \mathrm{~g} \mathrm{~L}^{-1}$ concentrations.

Filtration studies with vacuum assistance were also performed by applying vacuum to compress the thickness of the cake. Two variables were taken into consideration: time of gravity filtration and feed concentration of slurry. Feed volume was held constant at $400 \mathrm{~mL}$, and the duration of vacuum was constant at $1 \mathrm{~min}$. Gravity filtration cycles were 0 ,
3, 5, 7, 10, and $15 \mathrm{~min}$. Feed concentration was altered by diluting the original feed sample with water to ensure feed solids consistency.

For both the gravity and vacuum experiments, filtrate mass was recorded over a $60 \mathrm{~min}$ period. Cake thickness was measured with a digital Vernier caliper. The wet cake was removed from the filter medium, weighed for wet weight, dried at $100^{\circ} \mathrm{C}$, and reweighed for dry weight. The filter medium was washed with a bottle brush and rinsed between each trial, and the original sample of algae was gently mixed before each trial.

\section{RESULTS AND DISCUSSION}

Scenedesmus acutus was found to be negatively charged above $\mathrm{pH} 4$ and positively charged below $\mathrm{pH} 3$, exhibiting a point of zero charge (p.z.c.) at $\mathrm{pH} 3.5$. These results illustrate that in the $\mathrm{pH}$ range used for cultivation of these organisms using coal-fired flue gas as a $\mathrm{CO}_{2}$ source ( $\mathrm{pH} 5$ to 8), the cells are negatively charged, and electrostatic repulsive forces are the primary mechanism preventing agglomeration from occurring. Adjustment of the $\mathrm{pH}$ to the p.z.c. would minimize electrostatic repulsion, and natural flocculation would occur due to the shorter range of the bonding forces. However, doing so on a large scale would be problematic. Recycling clarified water after sedimentation would require raising the $\mathrm{pH}$ to a range suitable for cultivation; precipitation of soluble nutrients might also occur. On the other hand, naturally flocculated algae cells would have a very low settling rate due to the formation of very small flocs. It would be advantageous to induce flocculation at the natural $\mathrm{pH}$ of the growth system, producing flocs of sufficient size to achieve a rapid settling rate. Based on the electrokinetic behavior of algae cells, cationic flocculants were selected as suitable additives. While nonionic and anionic flocculants can induce flocculation of negatively charged algae cells due to polymer bridging effects, these additives were found to be ineffective, which is consistent with results reported by other researchers (McGarry, 1970; Tenney et al., 1969).

The relationship of turbidity (NTU) and dry mass concentration $\left(\mathrm{m} \mathrm{L} \mathrm{L}^{-1}\right)$ was found to be linear, with $\mathrm{R}^{2}=0.9686$. The calibration curve was based on the standardized turbidity of suspensions with varying algae concentrations and the dry mass concentration of the suspensions. Using this approach, clarified water quality was estimated without determining the dry mass concentration of each clarified water sample.

\section{FlocCUlation AND SEDIMENTATION}

Sedimentation tests showed that the 440 and 540 flocculants both performed better than the 6720 and alum (table 2). Where the ideal flocculant would minimize the algae cells remaining in suspension while minimizing the settled solids volume, 440 resulted in the smallest settled volume $(2.4 \mathrm{~mL}$ at $20 \mathrm{ppm})$, and 540 resulted in the lowest suspended solids (0 mg L-1 at $20 \mathrm{ppm})$. Using a lower MW flocculant (440) at a dosage of $40 \mathrm{ppm}, 6.7 \mathrm{~mL}$ of settled biomass accumulated after $10 \mathrm{~min}$, and further accumulation of $10 \mathrm{~mL}$ occurred after $30 \mathrm{~min}$; the supernatant contained $20 \mathrm{mg} \mathrm{L}^{-1}$ algae 
Table 2. Final settled volume, final turbidity of the supernatant, and estimated solids in the supernatant for the various flocculants tested at two concentration levels.

\begin{tabular}{ccccc}
\hline Flocculant & $\begin{array}{c}\text { Flocculant } \\
\text { Dosage } \\
(\mathrm{ppm})\end{array}$ & $\begin{array}{c}\text { Final } \\
\text { Settled } \\
\text { Volume } \\
(\mathrm{mL})\end{array}$ & $\begin{array}{c}\text { Solids in } \\
\text { Settled } \\
\text { Volume } \\
(\%)\end{array}$ & $\begin{array}{c}\text { Final Estimated } \\
\text { Algae in } \\
\text { Supernatant } \\
\left(\mathrm{mg} \mathrm{L}^{-1}\right)\end{array}$ \\
\hline 540 & 20 & 3.9 & 7.6 & 0 \\
& 40 & 2.9 & 3.1 & 4 \\
\hline 440 & 20 & 2.4 & 10.7 & 13 \\
& 40 & 9.8 & 2.9 & 20 \\
\hline 6702 & 20 & 0 & 0 & 253 \\
& 40 & 0 & 0 & 238 \\
\hline Alum & 100 & 25 & 0.25 & 155 \\
& 200 & 37 & 0.10 & 212 \\
\hline
\end{tabular}

(table 2). Decreasing the dosage of this flocculant to $20 \mathrm{ppm}$ provided only $2.4 \mathrm{~mL}$ of settled biomass after $20 \mathrm{~min}$ of settling and no additional accumulation after $30 \mathrm{~min}$. Using a higher MW flocculant (540) at $40 \mathrm{ppm}, 10 \mathrm{~mL}$ of biomass accumulated after 10 min with no further accumulation after $30 \mathrm{~min}$ and excellent supernatant clarity $\left(4 \mathrm{mg} \mathrm{L}^{-1}\right)$. At a lower dosage of $20 \mathrm{ppm}$, the higher MW flocculant provided only $3.9 \mathrm{~mL}$ of settled biomass.

At a dosage of $20 \mathrm{ppm}$, the lower MW 440 provided higher compaction of settled solids than the higher MW 540 ( $10.7 \%$ solids versus $7.6 \%$ solids). However, turbidity was higher for the lower MW 440. At a higher dosage of $40 \mathrm{ppm}$, both flocculants provided similar compaction (i.e., 2.9\% solids), and as with the lower dosage results, the higher MW 540 provided a less turbid supernatant. While both of these flocculants provided acceptable results, it is evident that the higher MW 540 provided better supernatant clarity. With respect to compacted solids, the lower MW 440 provided better compaction at the lower dosage, presumably due to the formation of smaller flocs, which provided better compaction.

The lower MW 440 resulted in a denser settled biomass at the $20 \mathrm{ppm}$ dosage, with over $10 \%$ solids in the settled layer. At the low dosage, some biomass adhered to the cone walls and inhibited compaction. Increasing flocculant dosage created larger flocs via bridging effects and therefore created a larger volume of compacted solids. While the 440 may have resulted in a slightly higher percentage of solids in the settled layer, the 540 achieved similar compaction results $66 \%$ faster (10 versus $30 \mathrm{~min}$ ).

The medium MW 6702 flocculant provided no settled biomass. At a dosage of $100 \mathrm{ppm}$ alum, $20 \mathrm{~mL}$ of biomass accumulated after $20 \mathrm{~min}$ and increased to a volume of $25 \mathrm{~mL}$ after $30 \mathrm{~min}$. At a higher dosage of $200 \mathrm{ppm}$ alum, $37 \mathrm{~mL}$ of biomass accumulated after $30 \mathrm{~min}$. Two distinct differences in settling performance were evident when alum was used: the volume of biomass was significantly higher and supernatant clarity was much poorer than with polymeric flocculants.

Flocs formed with alum were low in volumetric density and did not compact well. The resultant supernatant with alum contained 155 and $212 \mathrm{mg} \mathrm{L}^{-1}$ of suspended solids for alum dosages of 100 and $200 \mathrm{ppm}$, respectively. This is significantly higher than what was achieved with the polymeric flocculants. With alum treatment, even for the best results, approximately $75 \%$ of the biomass remained in the supernatant after $30 \mathrm{~min}$.



Figure 2. Final volume of settled algae for flocculant 540 with various dosages $(2.5,5,10,20$, and 30) and initial algae concentrations $(0.25$, 0.54 , and $1.012 \mathrm{~g} \mathrm{~L}^{-1}$ ) after $20 \mathrm{~min}$ of settling. Error bars are standard errors $(n=3)$. Final volumes with the same letter are not significantly different $(\alpha=0.05)$.

Figure 2 shows the results obtained with varying culture densities $\left(0.25,0.547\right.$, and $\left.1.012 \mathrm{~g} \mathrm{~L}^{-1}\right)$ using the higher MW 540 flocculant at varying dosages $(2.5$ to $30 \mathrm{ppm})$. For the lowest harvest culture density $\left(0.25 \mathrm{~g} \mathrm{~L}^{-1}\right)$, a dosage of $5 \mathrm{ppm}$ provided $7.3 \mathrm{~mL}$ of compacted solids. Increasing the dosage to $20 \mathrm{ppm}$ reduced the volume of compacted solids to $5 \mathrm{~mL}$. For a higher culture density $\left(0.55 \mathrm{~g} \mathrm{~L}^{-1}\right), 10 \mathrm{ppm}$ achieved $18.7 \mathrm{~mL}$ of solids, which compacted to less than $10 \mathrm{~mL}$ at a higher dosage. With the highest culture density tested $(1.0 \mathrm{~g}$ $\mathrm{L}^{-1}$ ), $10 \mathrm{ppm}$ provided $30 \mathrm{~mL}$ of settled solids, with no appreciable further compaction at higher dosages. These results suggest that a dosage of $10 \mathrm{ppm}$ is sufficient to provide settling of algae cells from culture densities as high as $1.0 \mathrm{~g}$ $\mathrm{L}^{-1}$, while higher dosages may provide further compaction. While it is intuitive that higher culture densities should require increased flocculant dosages to achieve acceptable settling performance, a dosage of $10 \mathrm{ppm}$ appeared to be sufficient even when the culture density was increased from 0.25 to $1.0 \mathrm{~g} \mathrm{~L}^{-1}$.

The effects of the higher MW 540 for a smaller range of dosages on a harvest culture density of $0.59 \mathrm{~g} \mathrm{~L}^{-1}$ are shown in figure 3. When considering the seven dosages ( 5 to $20 \mathrm{ppm}$ ), there was a significant dosage effect. The highest level of compaction was achieved with a dosage of $15 \mathrm{ppm}$, which provided $16.3 \mathrm{~mL}$ of compacted solids (3.3\% solids). However, there was no significant difference between the compactions above and below $15 \mathrm{ppm}$. Therefore, it should be possible to use the lower dosage of $12.5 \mathrm{ppm}$ to achieve 3\% solids for any harvest with a culture density near $0.5 \mathrm{~g} \mathrm{~L}^{-1}$.

\section{Filtration}

The algae filter cake was supported on the multifilament fabric $(901 \mathrm{~F})$ without algae cells passing through the woven medium. The filtrate from the multifilament medium contained only a negligible mass when filtered on Whatman No. 1 filter paper, and the turbidity was less than 5 NTU or $6 \mathrm{mg} \mathrm{L}^{-1}$, resulting in a capture efficiency greater than $99 \%$.

\section{Gravity Filtration}

Filtrate throughputs, in terms of the calculated cake solids via gravity filtration with variable feed volumes, are shown 




Figure 3. Effect of high MW 540 dosage on settled volume and calculated percentage of solids for harvest concentration of 0.589 g $\mathrm{L}^{-1}$. Error bars are standard error $(n=3)$. Values of settled volume or $\%$ solids with the same letter are not significantly different $(\alpha=0.05)$.

in figure 4 . The $16.5 \mathrm{~mm}$ cake was nearly $2.5 \times$ thicker than the smallest volume tested, which corresponds to the $2.5 \times$ increase in slurry volume introduced (i.e., $2.5 \times$ more biomass, given that the feed concentration was constant). The thinnest cake $(6.7 \mathrm{~mm})$ resulted from the $200 \mathrm{~mL}$ slurry volume, while the thickest cake $(16.5 \mathrm{~mm})$ resulted from the $500 \mathrm{~mL}$ slurry volume. The filtrate ratio (i.e., mass of filtrate to mass of feed,) was approximately 0.61 for the thickest cake and 0.55 for the thinnest cake. Cake formation time, typically seen as a sharp inflection of throughput under vacuum or pressure on denser suspensions, is defined as the time at which the filtration rate $(d V / d t)$ approaches zero. At this point, liquid can no longer freely migrate around deposited solids and must percolate through the established solid cake. The cake formation time was approximately 5 and $15 \mathrm{~min}$ for the thinnest and thickest cakes, respectively. The calculated volumetric throughput was $13.7 \mathrm{~mL} \mathrm{~min}^{-1}$ for the thinnest cake and $11.2 \mathrm{~mL} \mathrm{~min}^{-1}$ for the thickest cake. This indicates that a thinner cake would form faster, allowing higher belt and rotational speeds on corresponding belt and drum filters under continuous operation.
Figure 5 shows the cake solids (wt $\%$ ) after the final cakes were dried and weighed, removing residual and bound moisture. After $60 \mathrm{~min}$, the thinnest cake contained $7.5 \%$ algae solids by weight, while the thickest cake contained $8.8 \%$ solids by weight. With the density of the algae and water assumed to be equal, the biomass throughput rates would be 1.03 and $0.98 \mathrm{~g} \mathrm{~min}^{-1}$ for the thin and thick cakes, respectively, in this experiment.

For all volumes tested, given sufficient filtration time $(1 \mathrm{~h})$, the free water remaining can be reduced to between $23 \%$ and $29 \%$. Thicker algae cakes resulted in higher reductions in free water. Filtrate throughputs via gravity filtration with variable feed concentrations are shown in figure 6 . The $50 \mathrm{~g} \mathrm{~L}^{-1}$ concentration produced a cake thickness $\mathrm{f} 20.0 \mathrm{~mm}$, while the $30.25 \mathrm{~g} \mathrm{~L}^{-1}$ concentration produced a cake thickness of $15.7 \mathrm{~mm}$. The thicker slurry was approximately $1.65 \times$ more concentrated, while the thickness was only increased by approximately $1.27 \times$. The filtrate ratios were 0.5 and 0.3125 for the thinnest and thickest cakes, respectively. The cake formation times were 8 and 15 min for the thinnest and thickest cakes, respectively. The volumetric throughput

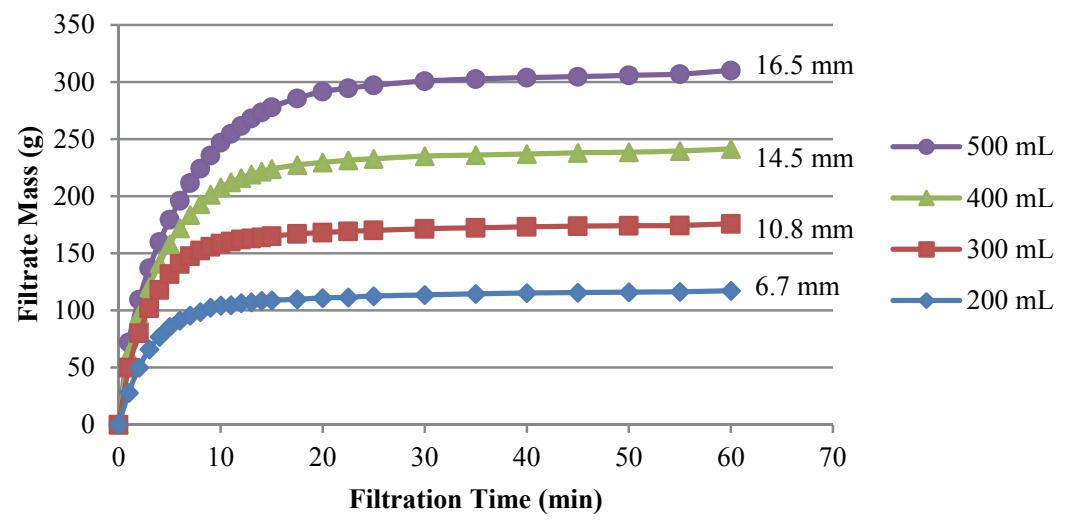

Figure 4. Gravity throughput for varied feed volumes with a constant feed concentration of $28.3 \mathrm{~g} \mathrm{~L}^{-1}$ of slurry with a large discrepancy in cake thickness (final cake thickness is shown at the end of each curve). 




Figure 5. Cake solids as a function of filtration time for varied feed volumes with a constant feed concentration of $28.3 \mathrm{~g} \mathrm{~L}^{-1}$ and gravity-assisted filtration.



Figure 6. Filtrate volume for gravity filtration for varied feed concentrations $\left(30,40\right.$, and $\left.50 \mathrm{~g} \mathrm{~L}^{-1}\right)$ for a constant feed volume of $400 \mathrm{~mL}$ of slurry. Final cake thicknesses are shown at the end of each curve.

was $19.9 \mathrm{~cm}^{3} \mathrm{~min}^{-1}$ for the thinnest cake and $13.6 \mathrm{~cm}^{3} \mathrm{~min}^{-1}$ for the thickest cake.

\section{Vacuum Filtration}

A series of tests was conducted to evaluate the plausibility of cake formation by gravity drainage, followed by a short duration of vacuum applied to the formed cake. The rationale of this dewatering approach was to determine whether vacuum applied after cake formation would facili- tate enhanced water removal while maintaining high solids capture. Figure 7 shows the filtrate throughputs of six cycles of gravity filtration, each followed by 1 min of vacuum application after cake formation. Each test was conducted with $400 \mathrm{~mL}$ of feed slurry (31.4 $\mathrm{g} \mathrm{L}^{-1}$ algae concentration). In the first test, vacuum was applied immediately (i.e., without allowing cake formation by gravity), and nearly $200 \mathrm{~g}$ of filtrate was removed after $1 \mathrm{~min}$ of vacuum filtration. In the

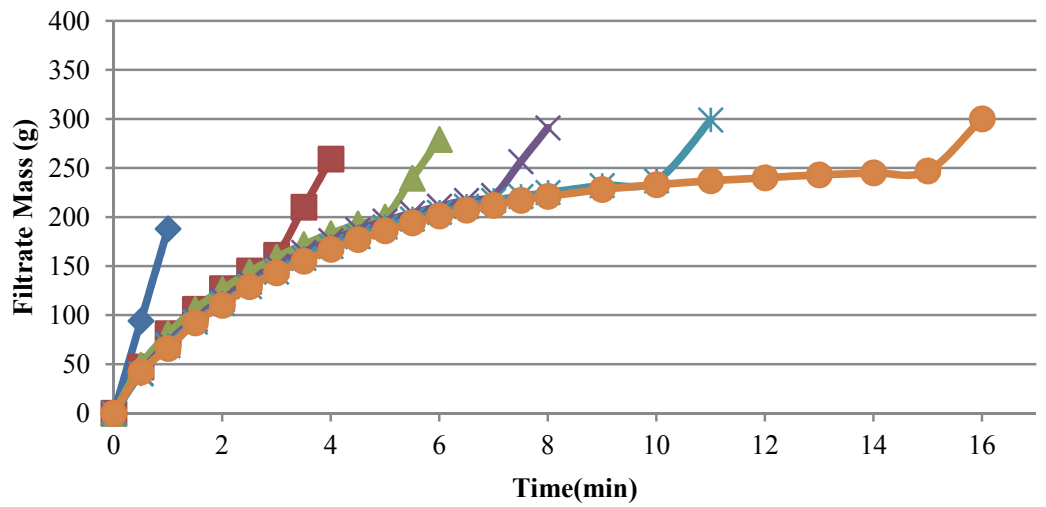

Figure 7. Mass of algae in filtrate over the course of filtration for varied cycle times for 1 min vacuum with feed concentration of $31.4 \mathrm{~g} \mathrm{~L}^{-1}$. 


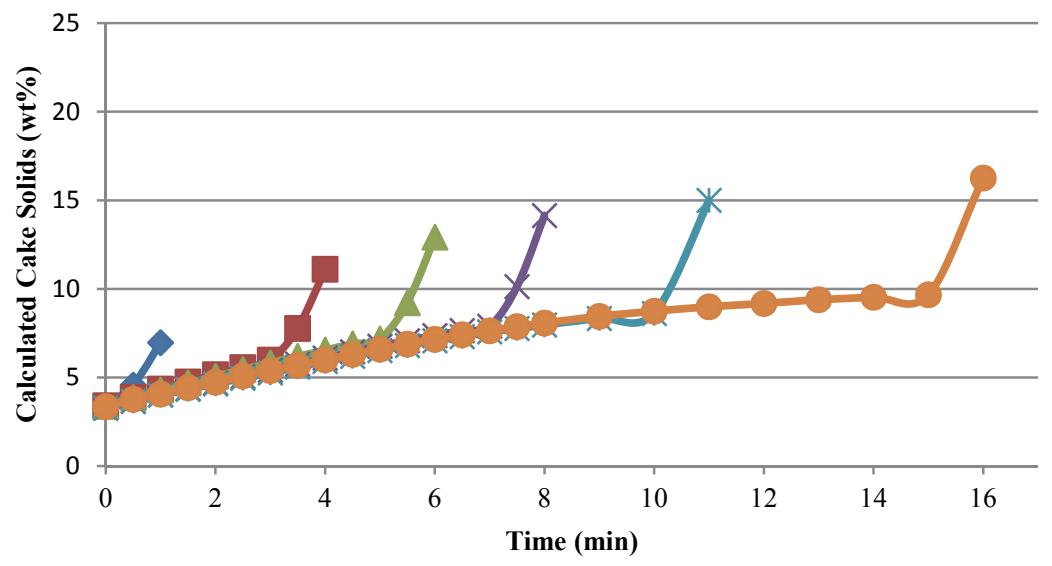

Figure 8. Cake solids for varied cycle times showing elevated solids content with vacuum for a feed concentration of $31.4 \mathrm{~g} \mathrm{~L}^{-1}$.

second test, a cake was formed with gravity drainage for $3 \mathrm{~min}$, after which vacuum was applied for an additional minute. In subsequent tests, cakes formed with gravity drainage for varying times $(5,7,10$, and $15 \mathrm{~min})$, and vacuum was applied for an additional minute after gravity drainage. The 16 min cycle time (15 min of gravity followed by $1 \mathrm{~min}$ of vacuum) produced a volumetric throughput rate of $6.25 \mathrm{~mL}$ $\mathrm{min}^{-1}$. No solids passed the fabric for any trial, even when no gravity drainage had occurred, suggesting that a gravity section of the belt may not be required to establish a cake using the $901 \mathrm{~F}$ (multifilament) medium.

Figure 8 shows the cake solids (wt\%) for the six cycle times in the previous trial. After the cake was formed after 7 min of gravity drainage, the cake solids were improved by over $80 \%$ with an additional minute of vacuum (i.e., total cycle time of $8 \mathrm{~min}$ ). The $16 \mathrm{~min}$ cycle time only improved the cake solids by $50 \%$, but the overall cake solids were approximately $16 \mathrm{wt} \%$. These results suggest that formed cakes can be dried mechanically with short durations of vacuum application, thereby minimizing the expense associated with continuous vacuum filtration. Results showed that drier cakes were produced with longer cake formation times.

\section{CONCLUSIONS}

Liquid cationic polymers can effectively flocculate microalgae cells and enhance settling, resulting in an algae slurry (20 to $50 \mathrm{~g} \mathrm{~L}^{-1}$ ) and a supernatant with low turbidity. The higher MW flocculant (540) aided the sedimentation of algae to the bottom of the Imhoff cones, requiring approximately $10 \mathrm{~min}$ for a total volume of $1 \mathrm{~L}$. Successful sedimentation removed at least $90 \%$ of the free water, indicating a reduction in downstream processing costs. In larger thickening vessels where wall effects are less influential, the slurry may potentially be subject to even higher compaction. Properly flocculated biomass could be further processed to extract even more water by mechanical means, such as filtration or centrifugation. Successful flocculation with a range of 540 flocculant dosages (5 to $30 \mathrm{ppm}$ ) effectively captured algae harvests from dilute suspensions $(0.25$ and $0.55 \mathrm{~g} \mathrm{~L}^{-1}$ ) up to a culture density of $1.0 \mathrm{~g} \mathrm{~L}^{-1}$. This versatility can provide ease of service in field applications.
When coupled with flocculation by cationic polymers, algae cells can be amenable to processing using industrialscale filtration systems. Multifilament filter media, such as $901 \mathrm{~F}$, can withstand the higher pressure gradient of vacuum assistance. Gravity filtration results suggested that thinner cakes provide slightly higher mass throughputs. The maximum solids content of cakes produced in this study was $25 \mathrm{wt} \%$, which is nearly double the content of algal biomass produced by disk stack centrifugation, which delivers a maximum of $12 \mathrm{wt} \%$ (Uduman et al., 2010). For products requiring thermal upgrading, filtered algal biomass would reduce the evaporation requirements by $380 \mathrm{MJ}^{-1}$ tonne ${ }^{-1}$. Other solids content ranges could be obtained by altering the filtration cycle times, pressures, and other parameters to meet the requirements of products along the wet biomass route. Based on the results obtained, a maximum production rate of $66 \mathrm{~kg}$ $\mathrm{m}^{-2} \min ^{-1}$ (dry basis) could be obtained from a feed concentration of $15 \mathrm{~g} \mathrm{~L}^{-1}$ with $901 \mathrm{~F}$ filter fabric by gravity filtration followed by a pulse of vacuum. Vacuum-assist belt filters can potentially be applied for large-scale algae culturing operations to dewater harvested algae to a range of solids contents for various end-use applications.

\section{ACKNOWLEDGEMENTS}

The authors would like to thank the Kentucky Department of Energy Development and Independence for funding. This material is based on work supported by the National Science Foundation under Cooperative Agreement No. 1355438. The information reported in this article (No. 1705-027) is part of a project of the Kentucky Agricultural Experiment Station and is published with the approval of the Director.

\section{REFERENCES}

Bare, W. F. R., Jones, N. B., \& Middlebrooks, E. J. (1975). Algae removal using dissolved air flotation. J. Water Pollut. Control Fed., 47(1), 153-169.

Chen, Y. M., Liu, J. C., \& Ju, Y.-H. (1998). Flotation removal of algae from water. Colloids Surf. B, 12(1), 49-55. https://doi.org/10.1016/S0927-7765(98)00059-9

Crofcheck, C., Xinyi, E., Shea, A., Montross, M., Crocker, M., \& 
Andrews, R. (2013). Influence of media composition on the growth rate of Chlorella vulgaris and Scenedesmus acutus utilized for $\mathrm{CO}_{2}$ mitigation. J. Biochem. Tech., 4(2), 589-594.

Divakaran, R., \& Sivasankara Pillai, V. N. (2002). Flocculation of algae using chitosan. J. Appl. Phycol., 14(5), 419-422. https://doi.org/10.1023/a:1022137023257

EPA. (1987). Design manual: Dewatering municipal wastewater sludges. EPA/625/1-87/014. 212. Washington, DC: U.S. Environmental Protection Agency.

Folkman, Y., \& Wachs, A. M. (1973). Removal of algae from stabilization pond effluents by lime treatment. Water Res., 7(3), 419-435. http://dx.doi.org/10.1016/0043-1354(73)90024-9

Friedman, A. A., Peaks, D. A., \& Nichols, R. L. (1977). Algae separation from oxidation pond effluents. J. Water Pollut. Control Fed., 49(1), 111-119.

Golueke, C. G., \& Oswald, W. J. (1965). Harvesting and processing sewage-grown planktonic algae. J. Water Pollut. Control Fed., 37(4), 471-498.

McGarry, M. G. (1970). Algal flocculation with aluminum sulfate and polyelectrolytes. J. Water Pollut. Control Fed., 42(5), R191R201.

Moraine, R., Shelef, G., Sandbank, E., Bar Moshe, Z., \& Schwarbard, L. (1980). Recovery of sewage born algae: Flocculation and centrifugation techniques. In G. Shelef, \& C. J. Soeder (Eds.), Algae biomass: Production and use (pp. 531546). Amsterdam, The Netherlands: Elsevier/North-Holland Biomedical Press.

Nigam, B. P., Ramanathan, P. K., \& Venkataraman, L. V. (1980). Application of chitosan as a flocculant for the cultures of the green alga Scenedesmus acutus. Arch. Hydorbiol., 88(3), 378387.

Shelef, G., Sukenik, A., \& Green, M. (1984). Microalgae harvesting and processing: A literature review. SERI/STR-231-2396.

Golden, CO: National Renewable Energy Laboratory. Retrieved from http://www.nrel.gov/docs/legosti/old/2396.pdf

Sim, T. S., Goh, A., \& Becker, E. W. (1988). Comparison of centrifugation, dissolved air flotation, and drum filtration techniques for harvesting sewage-grown algae. Biomass, 16(1), 51-62. http://dx.doi.org/10.1016/0144-4565(88)90015-7

Somasundaran, P. (1980). Principles of flocculation, dispersion, and selective flocculation. Proc. Intl. Symp. Fine Particles Processing (pp. 947-976). Englewood, CO: American Institute of Mining, Metallurgical, and Petroleum Engineers.

Sukenik, A., Bilanovic, D., \& Shelef, G. (1988). Flocculation of microalgae in brackish and sea waters. Biomass, 15(3), 187-199. http://dx.doi.org/10.1016/0144-4565(88)90084-4

Tenney, M. W., Echelberger, W. F., Schuessler, R. G., \& Pavoni, J. L. (1969). Algal flocculation with synthetic organic polyelectrolytes. Appl. Microbiol., 18(6), 965-971.

Uduman, N., Qi, Y., Danquah, M. K., Forde, G. M., \& Hoadley, A. (2010). Dewatering of microalgal cultures: A major bottleneck to algae-based fuels. J. Renew. Sustain. Energy, 2(1), 1-15. https://doi.org/10.1063/1.3294480

Vandamme, D., Pontes, S. C., Goiris, K., Foubert, I., Pinoy, L. J., \& Muylaert, K. (2011). Evaluation of electro-coagulationflocculation for harvesting marine and freshwater microalgae. Biotech. Bioeng., 108(10), 2320-2329. https://doi.org/10.1002/bit.23199

Wilson, M. H., Mohler, D. T., Groppo, J. G., Kesner, S., Frazar, E. M., Shea, A., ... Crocker, M. (2016). Capture and recycle of industrial $\mathrm{CO}_{2}$ emissions using microalgae. Appl. Petrochem. Res., 6(3), 279-293. https://doi.org/10.1007/s13203-016-0162-1

Zhou, X., Yuan, S., Chen, R., \& Ochieng, R. M. (2015). Sustainable production of energy from microalgae: Review of culturing systems, economics, and modelling. J. Renew. Sustain. Energy, 7(1), 1-29. https://doi.org/10.1063/1.4906919 